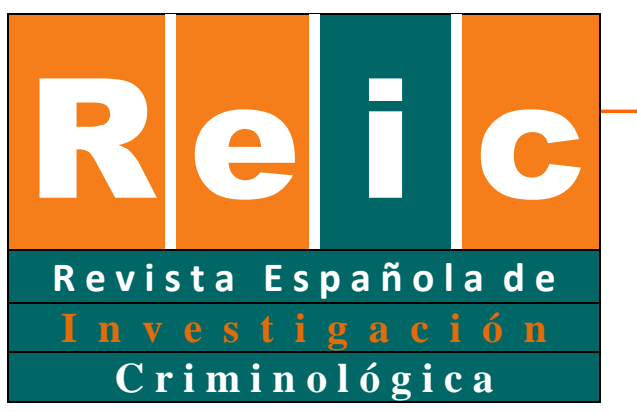

Camargo

\title{
Intergenerational transmission of child abuse in Colombia: an analysis of gendered effects
}

\author{
Transmisión intergeneracional del maltrato infantil en \\ Colombia: un análisis de los efectos del género
}

\author{
Esperanza Camargo ${ }^{1}$ iD \\ San Diego State University
}

\begin{abstract}
A broad range of research literature has studied patterns of intergenerational violence. However, scant research has looked at how those patterns are gendered. This study examines gendered patterns of intergenerational transmission of violence and looks at how gender relates to intimate partner violence and child physical abuse over time. I used a 2015 dataset of 12.915 interviews with Colombian heterosexual couples who were married or living together at the time of the interview. Using factor analysis and structural equation modeling (SEM), I found, consistent with previous studies, that parental history of child abuse was a predictor of physical child abuse; this is consistent with previous studies. Experiencing physical punishment by one's parents was a stronger predictor of the use of physical punishment on one's own children in adulthood than being an observer of partner violence between one's parents. However, the female observer of parental male-to-female partner abuse was more likely also to be a victim of intimate partner abuse in adulthood, and experiencing physical punishment by one's parents also predicts a male's physical victimization. Overall, the results support social learning theory and liberal feminist theory, that gender roles, gender inequality, and power structure are learned, passed from one generation to the next, and perpetuated by family relationships.
\end{abstract}

Keywords: child physical abuse, intergenerational transmission of violence, physical violence, parental history of child abuse

\footnotetext{
${ }^{1}$ La correspondencia debe dirigirse a: Department of Criminal Justice, San Diego State University, 5500 Campanile Dr. San Diego, CA 92182. ecamargo@sdsu.edu
}

Revista Española de Investigación Criminológica

Artículo 8, Número 16 (2018)

https://doi.org/10.46381/reic.v16i0.161

Www.criminologia.net

ISSN: 1696-9219 


\section{RESUMEN}

Los patrones de la transmisión intergeneracional de la violencia han sido estudiados en un considerable número de estudios. Pero, muy poca de esta literatura describe los patrones de transmisión por género. El presente estudio examina las diferencias por género en la violencia doméstica y el abuso infantil, así como también, la transmisión generacional de estos patrones. Para este estudio, se utilizó una muestra de 12,915 parejas heterosexuales colombianas, que estaban casadas o convivían cuando fueron entrevistadas en el año 2015. Los resultados del análisis factorial y de ecuaciones de modelos estructurales mostraron que la historia de abuso físico en la infancia de los padres predice el abuso físico a sus hijos e hijas. Estos resultados son consistentes con resultados obtenidos en estudios previos. Ser abusado físicamente por los padres tiene una relación causal más fuerte con el castigo físico a los hijos e hijas que presenciar violencia domestica entre los padres. Pero, el hecho de que las mujeres presencien el abuso físico de padre-a-madre predijo su victimización por sus parejas en la adultez. También, ser víctima de castigo físico por los padres predice la victimización física de los hombres por sus parejas. En general, los resultados de este estudio comprueban las teorías liberal-feminista y de aprendizaje; el rol de género, la inequidad por género, y la estructura de poder se aprenden, y, ese aprendizaje se pasa de una generación a la siguiente y se perpetúa a través de las relaciones familiares.

Palabras clave: maltrato infantil, transmisión intergeneracional de la violencia, violencia física, historia paterna de maltrato infantil

\section{Introduction}

A broad range of scholarship has found that child abuse is associated with intimate partner violence (Appel \& Holden, 1998; Cardenas V. \& Polo Otero, 2014; Herrenkohl, Sousa, Tajima, Herrenkohl, \& Moylan, 2008; Klevens, Bayon, \& Sierra, 2000; Straus, 1994; Wang, Xing, \& Zhao, 2014; Widom, Czaja, \& Dutton, 2014), family structure (Gonzalez, Trujillo, $\&$ Pereda, 2014) and with a history of family violence that parents experienced in early childhood either by witnessing domestic violence between their parents or by suffering physical punishment themselves (Ateah \& Durrant, 2005; Azar, 1997; Bensley et al., 2004; Briere \& Elliott, 2003; Dobbs, Smith, \& Taylor, 2006; Sanapo \& Nakamura, 2011; Straus \& Mathur, 1996). Also, a co-occurrence has been found between intimate partner physical abuse and child physical abuse (Friedemann-Sanchez \& Lovaton, 2012; Salas, 2005). However, there is scant research regarding the role of gender in both the production and the consequences of familial violence. This study addresses this shortcoming in an international

Revista Española de Investigación Criminológica

Artículo 8, Número 16 (2018)

https://doi.org/10.46381/reic.v16i0.161

www.criminologia.net

ISSN: 1696-9219 
context, focusing on the South American nation of Colombia. Using secondary data from a large interview sample of Colombian couples who were married or living together at the time of the interview, this study provides an assessment of intergenerational violence and traces some of its gendered implications. I am interested in the abusive behavior and history of both the father and the mother and the patterns associated with their offending behaviors as well as their victimization. I explore the gendered consequences of experiencing and witnessing violence in the family of origin, its relationship to intimate-partner violence, and its relationship with the subsequent use of physical punishment on their own children by parents who as children witnessed family violence (Gamez-Guadix, Straus, Carrobles, Munoz-Rivas, \& Almendros, 2010; Herrenkohl et al., 2008; Straus, 1991, 1994, 1996; Wang et al., 2014).

In this study, I first look at the pervasiveness of abuse, reviewing international research on the topic. I then review the research on gender in abuse, looking at the definitions and kinds of abuse that I will assess in the course of this study. Finally, I use a latent structural model to assess intergenerational patterns of abuse and differences in those patterns associated with gender.

\subsection{The Intergenerational Transmission of Violence: An International Problem}

Physical violence in the family is a widespread phenomenon and has been studied extensively. Of interest in this research is the way that abuse is gendered and how gender differences in patterns of abuse are transmitted across generations. Intergenerational transmission is understood to mean that "children learn how to behave both by experiencing how others [their parents] treat them and by observing how their parents treat each other" (Stith et al., 2000). The consequences of abuse are manifold (Devoe \& Smith, 2002); for instance, abused children face an increased risk of becoming abusers (Gratz, Paulson, Jakupcak, \& Tull, 2009; Hetzel-Riggin \& Meads, 2011; Mihalic \& Elliott, 1997; Ragin et al., 2002; Straus, 1991; Wang et al., 2014; Widom et al., 2014). Indeed, research has shown that the best predictor of adult violent behavior is childhood physical punishment (Caykoylu, Ibiloglu, Taner, Potas, \& Taner, 2011; Hetzel-Riggin \& Meads, 2011; Kandel, 1991; Oliver, 1993; Ragin et al., 2002; Straus, 1994). 
This pattern of intergenerational transmission has also been noted globally. Twentyone percent of Colombian females surveyed in 2005, for instance, reported suffering physical punishment during childhood, while $35 \%$ witnessed their fathers or stepfathers beating their mothers or stepmothers. Similar results were found in a sample from the Philippines, in which $61 \%$ of children had suffered physical punishment at home, especially by their mothers. Also, Filipino parents punished their sons more harshly than their daughters (Sanapo \& Nakamura, 2011). Studying a sample of 80 New Zealand children between 5 and 14 years old, Dobbs et al. found that $60 \%$ of them identified physical punishment as parental discipline (Dobbs et al., 2006; Straus, 1996). Twenty-five percent of Russian children and 60\% of Spanish college students also reported having been physically punished by their parents (Berrien, Aprelkov, Ivanova, Zhmurov, \& Buxhicheeva, 1995; Gamez-Guadix et al., 2010). In the United States, in a survey conducted by Briere and Elliott (2003), 22.2\% of females and $19.5 \%$ of males reported experiencing physical punishment in their childhood. An overview of the international literature suggests that gender differences in abuse and patterns of transmission of gender differences (Wang et al., 2014) are international issues, occurring independently of different cultural contexts, though cultural differences may shape the particular patterns, nature, and prevalence of the abuse.

It is important to define the central terms of this study at the outset. For the purpose of this paper, physical punishment is defined as "the use of physical force with the intention of causing a child to experience pain but not injury for the purposes of correction or control of the child's behavior" (Straus, 1994, p.4). Witnessing a violent event has been defined as "being within visual range of the violence and seeing it occur" (Edleson, 1999). I am also using the most recent definition of intimate-partner violence, which refers to "physical violence, psychological aggression, including coercive tactics, sexual violence, and stalking by a current or former intimate partner." Physical violence is defined as "the intentional use of physical force with the potential for causing death, disability, injury, or harm" (Edleson, 1999, p. 11), and psychological aggression is defined as the "use of verbal and non-verbal communications with the intent to: a) harm another person mentally or emotionally, and/or b) exert control over another person" (Breiding, Basile, Smith, Black, \& Mahendra, 2015). Psychological aggression can also communicate a traditional gendered status relationship in 
order to demonstrate male dominance, and as such, symbolic violence may occur to reaffirm an existing patriarchal power hierarchy and to police challenges to that order. Psychological aggression can include coercive control, such as "limiting access to transportation, money, friends, and family, excessive monitoring of a person's whereabouts, and communications" (Breiding et al., 2015).

Some form of physical punishment of children during childhood development is widespread and accepted globally. For example, 24\% of the parents in Briere and Elliott's research had experienced severe abuse (e.g., broken bones) in their childhood, $45 \%$ had experienced common physical punishment (e.g., being pinched), and $94.2 \%$ had been hit. Their expressed favorable perceptions of these behaviors were 6\%, 17\%, and $88 \%$, respectively. Interestingly, Bensley and her colleagues (2004), studying 504 adults from Washington State, found that around $25 \%$ of parents did not identify spanking as an abusive behavior. It may be that being abused as children increases the likelihood that violence against one's own children is legitimated. In a cross-sectional study using a sample of 449 parents, Buntain-Ricklefs and her colleagues found high prevalence and high levels of approval for physical punishment, while at the same time noting a significant correlation between culturally approved physical punishments and abusive behaviors (Burtain-Ricklefs, Kemper, Bell, \& Babonis, 1994), which supports the point made above about the cultural differences shaping the form and frequency of the abuse.

Physical punishment by parents has been noted across socioeconomic strata as well. Diezt compared the severity with which children were physically punished and found that parents with lower incomes and lower educational attainment were more likely to be physically abusive. They were more likely to describe child physical abuse in terms such as "hit [the] child with a hard object," "pinched [the] child," and "slapped [a] child on [the] face, head, [and/or] ears" than were parents from the middle and upper classes. This finding seems to suggest that physical punishment is more likely to be transmitted across generations in lower class circumstances, which supports an intersectionality perspective, though there could be reporting differences associated with shame in the upper and middle socioeconomic classes (Covey, Menard, \& Franzese, 2013; Davies et al., 2015; Dietz, 2000). 


\subsection{Mechanisms for the Intergenerational Transmission of Violence}

Intergenerational transmission can occur through a variety of mechanisms, and there are several starting points for the transmission process. One is that parents who were physically abused in childhood may use physical punishment to discipline their children (Caykoylu et al., 2011; Sanapo \& Nakamura, 2011; Wang et al., 2014). Another is that children may witness domestic violence between their parents (Appel \& Holden, 1998; Bernard \& Bernard, 1983; Ragin et al., 2002); witnessing and experiencing violence may "normalize" the use of violence to solve the conflict that naturally arises between family members. Moreover, intergenerational transmission of physical violence seems more likely in an environment that sustains and reinforces violence in some way. For instance, in lower class settings, rough punishment is perceived as the only way to keep children on track, especially by young, inexperienced, and financially stressed parents (Herrenkohl et al., 2008). Appel and Holden conducted a meta-analysis in 1998 and found that studies using either community-based samples or clinical samples reported a co-occurrence between intimate-partner violence and child physical punishment (Bernard \& Bernard, 1983). They observed that this occurred in five ways: single perpetrator (husband abused his wife and child), sequential perpetrator (husband abused his wife and she abused their child), dual perpetrator (both husband and wife abused their child), marital violence (both abused each other and their child), and family dysfunction (the three of them-husband, wife, and child-abused each other). Similarly, Herrenkohl and his colleagues (2008), in a review of approximately 500 relevant research articles, found evidence supporting the child physical punishment-intimate-partner abuse cooccurrence. Furthermore, the context surrounding violence and when its use is considered appropriate may be reinforced by media representations and transmission of images of violence as a problem-solving or coping mechanism, as Bandura originally pointed out (Bandura, 1977) and as has been noted in other studies of violence and non-violence (Barak, 2003).

The constant use of violence by parents as witnessed by their children may also serve to model violent behavior for their children, for both the abuser and the victim (Ateah \& Durrant, 2005; Azar, 1997; Kandel, 1991). For instance, similar patterns of the use of 
interpersonal violence have been found among college students and their parents (Muller, Hunter, \& Stollak, 1995). Oliver also noted that approximately $30 \%$ of the offspring of neglected, inept, or abusive parents displayed similar behaviors toward their own children (Oliver, 1993). Moreover, studying a sample of 44 abuser and non-abuser males, Caesar (1988) found that abusers were more likely to have been abused physically as children and to have witnessed their mothers' abuse by their fathers or stepfathers. Simons and his colleagues, using 204 divorced mothers, found that females exposed to harsh physical punishment in childhood were more likely to remain in abusive intimate relationships. They also found that harsh maternal punishments were associated with traditional gender beliefs (Simons, Johnson, Beaman, \& Conger, 1993).

Not all researchers, however, have found the same association. For instance, analyzing a large sample of 14,138 children and their mothers during a period of eight years, researchers from the Avon Longitudinal Study of Parents and Children (ALSPAC) study team found that the correlation between child abuse and parental history of abuse was not statistically significant, controlling for sociodemographic variables (Sidebotham, Golding, \& Study, 2001). And in a meta-analysis, Stith et al. (2000) found that the relationships between early child abuse and spouse abuse was weak to moderate.

\subsection{Gender Consequences of Child Abuse}

Research on the gendered consequences of abuse is limited. A longitudinal study of 299 children and their mothers who were interviewed twice in a period of five years found that exposure to intimate-partner violence predicted referral to juvenile courts and that boys were more likely than girls to be referred for property and violent felonies. Girls with a history of physical abuse were more likely to be arrested for violent offenses than for any other type of offense (Herrera \& McCloskey, 2001). Experiencing and witnessing violence was associated with intimate-partner abuse, child abuse, and delinquency (Mihalic \& Elliott, 1997), and experiencing several types of abuse was found to be strongly correlated with partner maltreatment, child physical abuse, and with witnessing family violence (Hetzel-Riggin \& Meads, 2011).

\section{Revista Española de Investigación Criminológica}

Artículo 8, Número 16 (2018)

www.criminologia.net

ISSN: 1696-9219 
A further consideration in relation to the gendered structure of violence is that patterns of violence over time are not always or only transmitted interpersonally but that they have multiple sources at different levels of social structure and that each can reinforce the other. For example, in Violence and Nonviolence: Pathways to Understanding, Gregg Barak said that there is clear evidence that the causes of violence are cumulatively interrelated across a range of societal levels. He noted that the causes of violence (and nonviolence) range "across the spheres of interpersonal, institutional and structural relations as well as across the domains of family, subculture and culture are cumulative, mutually reinforcing, and inversely related" (Barak, 2003, p. 169). He further argued that we need to account for the dynamic interrelations of these different levels in order to understand the pathways to violence (Barak, 2003, p. 170). Moreover, in relationship to the present study, he argued that occurrences of violence at these different levels can themselves be implicated in the causes of subsequent acts of violence as the process of violence unfolds over time. This would include intergenerational gendered violence and how the pattern of gendering manifests at the local interpersonal level can be shaped and reinforced by patterns at the meso-level (community and neighborhood violence), macro-level (societal-level violence, state violence), and even global-level gender violence, such as occurs in some parts of the world where abuse of women and exploitation of children are built into the fabric of their patriarchal societies, cultural values, and routine practices and are communicated globally via social media. Elsewhere, Barak observed that we need to consider the full range of behavioral motivations and sociocultural constraints that intersect with the spheres of interpersonal, institutional, and structural communication (Barak, 2006). Clearly, such an analysis has implications for any policy that is based only at the interpersonal level.

\section{Methods}

\subsection{Participants}

This secondary data sample of 12.915 couples is demographically representative of the Colombian population; in 2015, at the time of the interview, $33 \%$ of the respondents were 
living in rural areas and $67 \%$ in urban areas. It is also proportionally representative of the relative populations of the Colombian regions: Atlántica (27\%), Oriental (14\%), Central (22\%), Pacífica (15\%), Bogotá (5\%), and Orinoquía and Amazonía (18\%). The respondents identified themselves as mestizo (77\%); indigenous (13\%); black (9\%); and Roma, Gypsy, and Palenquero (1\%). On average, females had 8.75 years of education while males had 8.19 years.

With regard to the prevalence of violence at home, both female and male respondents reported violence in their relationships with their parents, intimate partners, and children. Ten percent of female respondents and $8 \%$ of male respondents reported that they were spanked by their parents; $62 \%$ of female respondents and $73 \%$ of male respondents reported that they were hit with objects by their parents. Moreover, 34\% of female respondents and $29 \%$ of male respondents witnessed their mother being beaten or hit by her intimate partner. Also, both female and male respondents reported physical violence by their partners and had used physical punishment toward their own children (see Table 1). 


\section{Table 1.}

Demographic of the Sample $(N=12.915)$

\begin{tabular}{|c|c|c|c|c|}
\hline & $\mathbf{N}$ & $\%$ & & \\
\hline \multicolumn{3}{|l|}{ Region } & & \\
\hline Atlántica & 3.427 & 26.5 & & \\
\hline Oriental & 1.818 & 14.1 & & \\
\hline Central & 2.833 & 21.9 & & \\
\hline Pacífica & 1.959 & 15.2 & & \\
\hline Bogotá & 602 & 4.7 & & \\
\hline Orinoquía/Amazonía & 2.276 & 17.6 & & \\
\hline \multicolumn{3}{|l|}{ Location of residence } & & \\
\hline Urban & 8.604 & 66.6 & & \\
\hline Rural & 4.311 & 33.4 & & \\
\hline \multicolumn{3}{|l|}{ Wealth } & & \\
\hline Poorest & 4.311 & 33.4 & & \\
\hline Poorer & 3.757 & 29.1 & & \\
\hline Middle & 2.279 & 17.6 & & \\
\hline Richer & 1.615 & 12.5 & & \\
\hline \multirow[t]{3}{*}{ Richest } & 953 & 7.4 & & \\
\hline & \multicolumn{2}{|c|}{ Female Respondent } & \multicolumn{2}{|c|}{ Male Respondent } \\
\hline & $\mathbf{N}$ & $\%$ & $\mathbf{N}$ & $\%$ \\
\hline \multicolumn{5}{|l|}{ Educational Attainment } \\
\hline None & 375 & 2.9 & 533 & 4.1 \\
\hline High school or lower & 9.297 & 72.0 & 9.616 & 74.5 \\
\hline
\end{tabular}

Revista Española de Investigación Criminológica

Artículo 8, Número 16 (2018)

www.criminologia.net

ISSN: 1696-9219 


\begin{tabular}{|c|c|c|c|c|}
\hline Higher education & 3.243 & 25.1 & 2.766 & 21.4 \\
\hline \multicolumn{5}{|l|}{ Physical violence in the family of origin } \\
\hline Respondent was hit/beaten with an object by parents/guardians & 7.982 & 61.8 & 9.358 & 72.5 \\
\hline Respondent witnessed her/his mother being hit/beaten by her husband & 4.364 & 33.8 & 3.716 & 28.8 \\
\hline Respondents hits/beats with an object their own children & 3.381 & 26.2 & 2.429 & 18.8 \\
\hline \multicolumn{5}{|l|}{ Respondents approval to male coercive control toward women } \\
\hline Real men can control their partners & 5.971 & 46.2 & 6.362 & 49.3 \\
\hline A good wife always obeys her husband & 6.275 & 48.6 & 8.400 & 65.0 \\
\hline It is expected that men do not allow their wives to go out alone & 2.689 & 20.8 & 3.787 & 29.3 \\
\hline \multicolumn{5}{|l|}{ Respondents approval of violence against women } \\
\hline Sometimes men can hit their female partners & 425 & 3.3 & 496 & 3.8 \\
\hline Men can hit their female partners if they are unfaithful & 860 & 6.7 & 1.211 & 9.4 \\
\hline \multicolumn{5}{|l|}{ Psychological aggression: Did your partner... } \\
\hline act jealous when you talk with another man/woman & 3.941 & 30.5 & 5.787 & 44.8 \\
\hline accuse you of being unfaithful & 2.242 & 17.4 & 4.083 & 31.6 \\
\hline not allow you to meet friends & 1,861 & 14.4 & 2.236 & 17.3 \\
\hline try to limit your contact with family & 845 & 6.5 & 773 & 6.0 \\
\hline insist on knowing where you were at all times & 2.702 & 20.9 & 3.365 & 26.1 \\
\hline monitor how you spent your money & 1.154 & 8.9 & 2.050 & 15.9 \\
\hline ignore/not address you with the intention of being spiteful & 2.569 & 19.9 & 320 & 2.5 \\
\hline \multicolumn{5}{|l|}{ Physical violence: Did your partner... } \\
\hline push or shake you & 1.627 & 12.6 & 1.917 & 14.8 \\
\hline slap you & 1.017 & 7.9 & 1.430 & 11.1 \\
\hline punch you with his fist or hit you & 261 & 2.0 & 601 & 4.7 \\
\hline kick you & 334 & 2.6 & 182 & 1.4 \\
\hline
\end{tabular}

Revista Española de Investigación Criminológica

Artículo 8, Número 16 (2018)

Www.criminologia.net

ISSN: 1696-9219 
try to strangle or burn you

164

301

1.3

107

282

0.8

Revista Española de Investigación Criminológica

Artículo 8, Número 16 (2018)

www.criminologia.net

ISSN: 1696-9219 


\subsection{Measures}

Two scales were used to measure respondents' approval toward male coercive behavior toward women, i.e. their approval of coercive behavior toward women and their approval of violence against women.

Respondents' approval of coercive behavior toward women: This scale measures the respondents' favorable opinion of male coercive behaviors toward women and may partially explain the normalization of power structure and gender inequality in Colombia. Three dichotomous ( $\mathrm{Y} / \mathrm{N})$ items were included to measure this dimension. Respondents were asked if they agreed with the following statement: (1) Real men can control their partners, (2) A good wife always obeys her husband, and (3) It is expected that men do not allow their wives to go out alone.

Respondents' approval of violence against women: This scale measures the respondent's favorable opinion of violence against women. Two dichotomous $(\mathrm{Y} / \mathrm{N})$ items were included: (1) Sometimes, men can hit their female partners, and (2) Men can hit their female partners if they are unfaithful.

Psychological aggression, including coercive control: A modified version of the MEASURE DHS (Demographic and Health Survey) scale was used to assess psychological aggression between intimates during the 12 months prior to the interview. Five items that fit the most parsimonious model were included to measure verbal and nonverbal actions by individuals with the intention of hurting their intimate partner. The respondents were asked if their partner does any of the following: (1) accuse you of being unfaithful, (2) act jealous when you talk with another man/woman, (3) prohibit you from meeting friends, (4) try to limit your contact with your family, (5) insist on knowing where you were at all times, (6) monitor how you spent money, and (7) ignore you or not address you, with the intention of being spiteful.

Physical violence: A modified version of the MEASURE DHS scale was used to assess this dimension. The following six items were included: did your partner (1) push or shake you, (2) slap you, (3) punch you with his/her fist or hit you, (4) kick you, (5) try to strangle or burn you, and (6) threaten you with a knife, a gun, or any other weapon. 
Observed variables: The following variables were included: (1) respondents witnessed their mother being hit or beaten with an object by their father or stepfather; (2) respondents were physically punished by their parents or caregivers in childhood; (3) respondents physically abuse their partners; and (4) respondents physically punish their own children. Moreover, I analyzed the effects of three sociodemographic variables: wealth $(1=$ poor and poorest, $2=$ middle, $3=$ rich and richest $)$; location of residency $(1=$ urban, $2=$ rural), and education ( $0=$ none, $1=$ high school or lower, 2 = vocational or higher education $)$.

\subsection{Sample}

This study uses the 2015 Colombian dataset gathered by MEASURE DHS, a United Nations program that funds and provides technical support to countries to survey their populations every five years regarding topics such as nutrition, health, family planning, and family violence. The survey included 44,614 households; for the present study, a subset of 12,915 heterosexual couples who were married or living together at the time of the interview was used. The couple partners were interviewed separately and privately using the specific questionnaires designed for male and female respondents. The 'disproportionate stratified sampling' technique was used to assure representativeness by region; a weight number is used to correct the effects of oversampled (e.g. Bogota) and undersampled (e.g. Orinoquia and Amazonia) populations.

\subsection{Procedure}

I carried out exploratory factor analyses and exploratory structural equation modeling (SEM). Because a few of the variables did not have a normal distribution and displayed high levels of skewness and kurtosis, I also carried out SEM using the weighted least square mean variance (WLSMV) estimator. This estimator is provided by Mplus modeling software to conduct the analysis of dichotomous, non-normally distributed variables (Muthen, 1983, 1984; Muthen \& Muthen, 2009). The model fit the data, as is demonstrated by the indicators 
of good fit (Arbuckle, 2006), that is, CFI $=0.980, \mathrm{TLI}=0.975, \mathrm{RMSEA}=0.018$, Chi-Square $=4696.732(\mathrm{df}=874, \mathrm{p}=0.000)$, and the strength of the factor loadings.

\section{Results}

Based on Leary (2003), I found weak (below, at, or about .1), moderate (around .3), and strong (over .5) correlations between factors and among factors and observed variables (Cohen, 1990; Leary, 2003). These relationships were found to be highly significant.

\section{Intimate Partner Violence}

Both categories of victimization - physical violence and psychological aggression-were correlated; against the women (.70) and against men (.65). However, psychological aggression against men was also correlated with women's physical (.32) and psychological (.36) victimization. Moreover, men's physical victimization was correlated with his female partner's physical (.41) and psychological (.33) victimization (see Table 2).

\section{Intimate Partner Violence and Violence in The Family of Origin}

The female's experience of physical punishment is inversely correlated with her partner' psychological victimization (-.11) and his favorable perceptions of coercive behavior toward women (-.11). Both the male's experience of physical punishment and witnessing his mother being hit by her intimate partner were predictors of his physical victimization (.19 and .21, respectively). His physical victimization was correlated with his use of physical punishment on his children (.19) (see Table 2). 


\section{Table 2.}

Factor Correlations

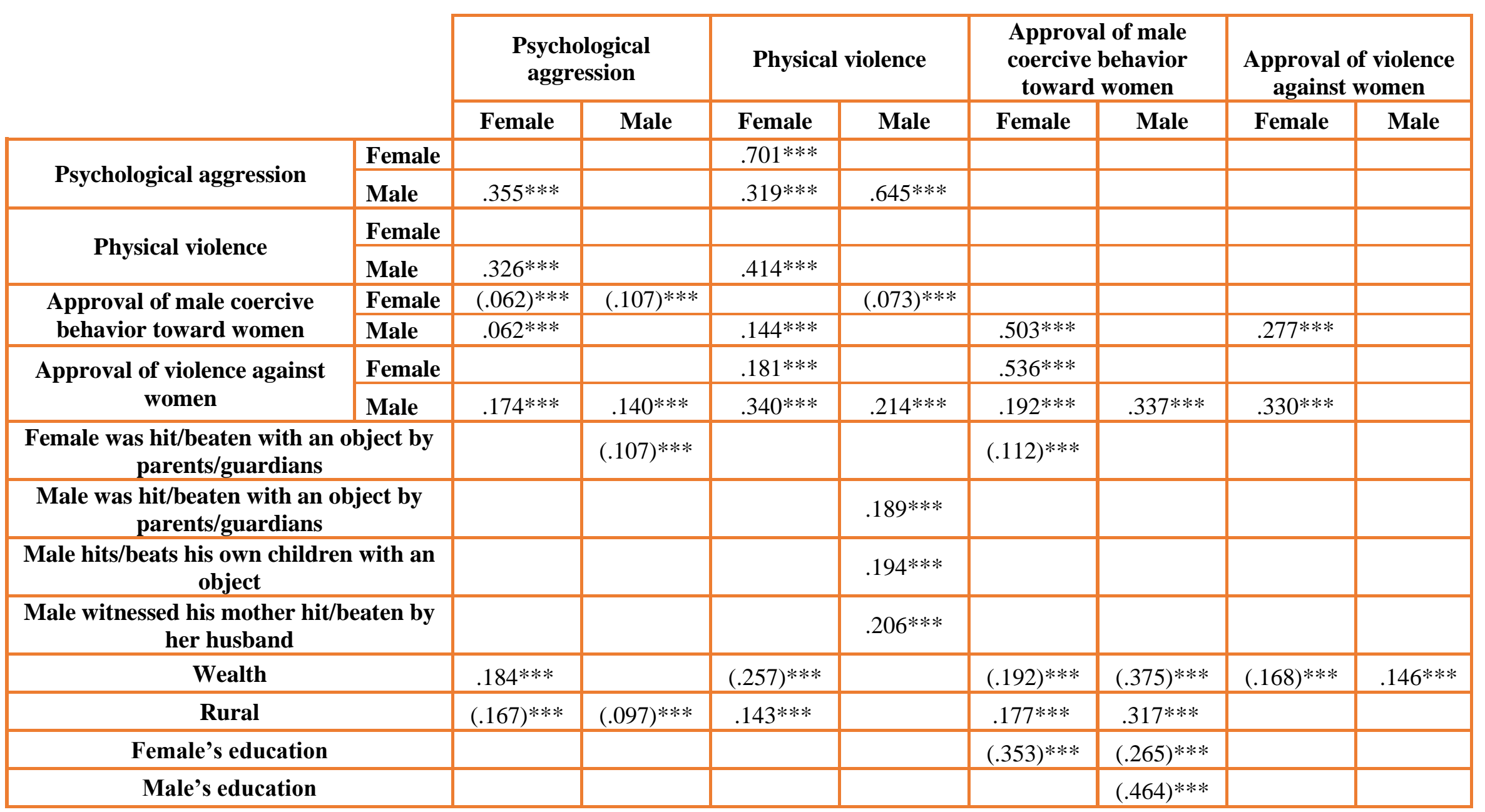

Note: This table shows only correlations at the significance level $p<0.000$. Inverse correlations are shown in parentheses.

Revista Española de Investigación Criminológica

Artículo 8, Número 16 (2018)

www.criminologia.net

ISSN: 1696-9219 


\section{Intimate Partner Violence and Demographics}

Psychological aggression against women was correlated with wealth (.18) but inversely correlated with rural areas (-.17). Psychological aggression against the husband was also inversely correlated with rural areas (-.10). Physical violence against the wife was correlated with rural areas (.14) and inversely correlated with wealth (-.26). The wife's approval of coercive behavior toward women was inversely correlated with wealth (-.19) and with her education (-.35), and directly correlated with rural areas (.18). Her approval of violence against women was inversely correlated with wealth (-.17). The husband's approval of coercive behavior toward women was correlated with rural areas (.32) but inversely correlated with wealth (-.38), women's education $(-.27)$, and the husband's education (-.46). Interestingly, the husband's approval of violence against women was correlated with wealth (.15) (see Table 2).

\section{Female Approval of Coercive Behavior Toward Women}

This was inversely correlated with the wife's (-.06) and her husband's (.11) psychological victimization. It also was inversely correlated with her husband's physical victimization (.07). Moreover, the wife's approval of violence against women was correlated with her physical victimization (.18) and her approval of coercive behavior toward women (.54) (see Table 2).

\section{Male Approval of Coercive Behavior Toward Women}

This was correlated with the wife's psychological (.06) and physical (.14) victimization, her favorable attitudes to male coercive behavior toward women (.50) and her approval of violence against women (.28). Male approval of violence against women was correlated with his wife's psychological (.17) and physical (.34) victimization as well as with his physical (.21) and psychological (.14) victimization. Moreover, it was correlated with his (.34) and his wife's approval of male coercive behavior toward women (.19) and with her approval of violence against women (.33) (see Table 2).

\section{Violence in the Family of Origin}

Wives and husbands witnessing their mother being hit by their father or stepfather were correlated (.13). Also, there is a correlation between her and his experience of physical punishment in childhood (.20) and a co-occurrence between experiencing physical punishment and witnessing 
their mother being hit by their father or stepfather (i.e., .30 and .32 for the wife and the husband, respectively). A wife's parents' use of physical punishment to discipline her was a predictor of her use of physical punishment on her own children in adulthood (.41). This correlation was .42 for the husband. Witnessing her mother being hit by her father or stepfather was also a predictor of her use of physical punishment on her own children (.15). The husband's experience of physical punishment in childhood was a predictor of his wife's use of physical punishment on their children (.13). The husband witnessing his mother being hit by his father or stepfather and using physical punishment on his own children were correlated (.13). The wife's experience of physical punishment and witness of her mother being hit were predictors of the husband's use of physical punishment on their children (i.e., .20 and .40, respectively) (see Table 3). 


\section{Table 3.}

Violence in Family of Origin and Demographics

\begin{tabular}{|c|c|c|c|c|c|c|c|c|}
\hline & \multirow[b]{2}{*}{$\begin{array}{l}\text { Female was } \\
\text { hit/beaten with an } \\
\text { object by } \\
\text { parents/guardians }\end{array}$} & \multirow[b]{2}{*}{$\begin{array}{c}\text { Female } \\
\text { hits/beats } \\
\text { her own } \\
\text { children } \\
\text { with an } \\
\text { object }\end{array}$} & \multirow[b]{2}{*}{$\begin{array}{c}\text { Female } \\
\text { witnessed } \\
\text { her } \\
\text { mother } \\
\text { hit/beaten } \\
\text { by her } \\
\text { male } \\
\text { partner }\end{array}$} & \multirow[b]{2}{*}{$\begin{array}{c}\text { Male was } \\
\text { hit/beaten with an } \\
\text { object by } \\
\text { parents/guardians }\end{array}$} & \multirow[b]{2}{*}{$\begin{array}{l}\text { Male } \\
\text { hits/beats } \\
\text { his own } \\
\text { children } \\
\text { with an } \\
\text { object }\end{array}$} & \multirow[b]{2}{*}{ Wealth } & \multirow[b]{2}{*}{ Rural } & \multirow[b]{2}{*}{$\begin{array}{l}\text { Female's } \\
\text { education }\end{array}$} \\
\hline & & & & & & & & \\
\hline $\begin{array}{l}\text { Female hits/beats her own } \\
\text { children with an object }\end{array}$ & $.414 * * *$ & & & & & & & \\
\hline $\begin{array}{l}\text { Female witnessed her } \\
\text { mother hit/beaten by her } \\
\text { husband }\end{array}$ & $.296^{* * *}$ & $.146^{* * * *}$ & & & & & & \\
\hline $\begin{array}{l}\text { Male was hit/beaten with an } \\
\text { object by parents/guardians }\end{array}$ & $.201 * * *$ & $.128 * * *$ & & & & & & \\
\hline $\begin{array}{l}\text { Male hits/beats his own } \\
\text { children with an object }\end{array}$ & $.195^{* * *}$ & $.393 * * *$ & & $.420 * * *$ & & & & \\
\hline Rural & & & & & $.083 * * *$ & $(.844) * * *$ & & \\
\hline Female's education & $(.096)^{* * *}$ & & & & & $.272 * * *$ & $(.307)^{* * *}$ & \\
\hline Male's education & $(.068)^{* * *}$ & & & & & $.242 * * *$ & $(.28)^{* * *}$ & $.573 * * *$ \\
\hline Female as head of household & & & & & & & $(.202)^{* * *}$ & \\
\hline
\end{tabular}

Note: This table shows only correlations at the significance level $p<0.000$. Inverse correlations are shown in parentheses. 


\section{Physical Violence and Demographics}

People living in rural areas are poorer and less educated, as shown by the inverse correlation with wealth (-.85), women's education $(-.31)$, and men's education (-.28). And, in rural households, women were not likely to be the head of the household $(-.20)$. The husband's and the wife's education was correlated (.57). The wife's education was inversely correlated with her parents' physical punishment of her (-.10) and directly correlated with wealth (.27). The husband's education was directly correlated with wealth (.24) and inversely correlated with his wife's experience of physical punishment in childhood (.07) (see Table 3).

\section{Discussion}

The model's measures of fit are excellent. The results of this study support the hypothesis that parental history of child abuse predicts current child abuse. As shown in table 1, both male and female respondents reported violence in their family of origin as well as violence in their own current family. For them, being physically punished by their parents and witnessing their mother being hit by their father or stepfather were predictors of their use of physical punishment on their own children (see Table 3). However, experiencing physical punishment is a stronger predictor of the transmission of violence from one generation to the next than witnessing it among their parents.

I also found support for the statement that there are gendered differences in abuse outcomes. As shown in table 2, being physically punished by one's parents was a predictor for psychological aggression against women, but it is a stronger predictor of men's physical victimization. In addition, receiving physical punishment as a child protects men from subsequent psychological aggression by their female partners. Witnessing one's mother being hit by her intimate partner was a predictor of intimate partner abuse against women, but again, it is a stronger predictor of the husband's physical victimization. In other words, male victims of physical violence in childhood may be attracted to women with abusive tendencies (see Table 2), which could be one of the factors that perpetuates the vicious cycle of violence. 
The results also suggest that by larger margins, based on gender role expectations, Colombians approve of male coercive behavior, including violence against women. For example, on average, $39 \%$ of female and $48 \%$ of male respondents agreed with a type of masculinity that is controlling, and $5 \%$ and $7 \%$, respectively, agreed that physical violence is expected. However, the correlations are stronger for male respondents, as they are correlated with their female partners' and their own physical and psychological victimization (see table 2). Women who were not hit by their parents do not agree with male coercive behavior or violence against women. Moreover, men and women's favorable perceptions of male coercive behavior toward women are correlated. This suggests that couples tend to share gender role expectations surrounding violence in the family. Finally, the findings in this Colombian sample support the power-control theory argument that gender inequality and violent behavior are transmitted by the patriarchal family.

\subsection{Limitations and Future Research}

Even though this study contributes to the literature on transmission of violence and its gendered consequences, there are three limitations. First, since this study used a sample of heterosexual Colombian couples who were married or living together and have children at the time of the interview, its results are generalizable to the two-parent nuclear and extended families that in 2014 accounted for 59\% of the Colombian households (Observatorio-dePoliticas-de-las-Familias, 2016-2, 2016). Future analyses of the transmission of violence must estimate the proportion and include LGBT married or living together couples with children that are currently grossly underestimated $(0.12 \%)($ Observatorio-de-Politicas-delas-Familias-2016-1, 2016). Second, future studies must analyze regional differences in the transmission of violence, since, a) there are regional differences in the use of violence in the family; for example, the Oriental region showed higher levels of child physical abuse, low levels of non-violent child-rearing tactics in female's childhood (Camargo, 2009) and Bogotá showed the highest levels of violence against women, while the Atlántica region showed the lowest (Baron, 2010), and b) the levels of masculine domination may differ by race and socioeconomic status. Black masculinity is often associated with sexuality while mestizo's

Revista Española de Investigación Criminológica

Artículo 8, Número 16 (2018)

www.criminologia.net

ISSN: 1696-9219 
masculinity is associated with religiosity and power (Viveros Vigoya, 2002). Finally, because the Colombian family is predominantly patriarchal (Observatorio-de-Politicas-delas-Familias-2016-2, 2016) with high levels of gender inequality (Bonilla-Mejia, 2011), these findings must be tested in developed countries with more egalitarian gender perspectives.

\subsection{Conclusion}

This study contributes to four aspects of policy development. First, in so far as there may be a "normalization" of the use of violence by the patriarchal Colombian family, Colombia should develop programs and policies to prevent violence in the family, empower women, and promote the understanding of different types of masculinity that are not associated with violence or control. My analysis shows that both witnessing and experiencing physical violence in childhood predicts one's use of violence in adulthood against one's partner and/or one's children and that it may be reinforced by an understanding of the kind of masculinity that is tough, controlling, and violent, as is shown by the favorable perceptions of male coercive behavior, including violence against women, and its correlation with the use of violence at home. However, as the work of Barak (2003) indicated, programs directed at the micro-level may be insufficient without also developing policies at the meso- and macrolevel, including manifestations and images of violence and patriarchy that permeate Colombian culture.

Second, child abuse has gendered consequences. As these results show, although the impact of violence in the family of origin affects boys and girls, the effect is stronger in boys. Therefore, the prevention of violence against women and girls must include prevention of violence against boys. Such prevention will also facilitate the development of a conception of masculinity that respects and values women.

Third, violence at home is transmitted from one generation to the next, which suggests that any solution must include cultural changes and beliefs regarding gender roles and expectations.

Finally, there are macro-level socioeconomic conditions that facilitate the occurrence of these phenomena and its intergenerational transmission. The conditions of poverty provide 
a fertile environment for the use of violence, as shown by the correlation between poverty and violence in both the family of origin and the actual family. However, the results also show a cultural component, since wealthy women may be victims of psychological aggression by their male intimate partners, and highly educated men may have favorable perceptions of violence against women.

In sum, this study provides evidence for the intergenerational transmission of violence, and therefore, supports Hagan's power-control rationale. The findings suggest that the pattern of intergenerational transmission is gendered and that this gendering of violence has both roots and support in multiple sources and sites in Colombian society. For both males and females, childhood physical abuse predicted their use of physical punishment of their own children. In addition, sociodemographic variables moderate the effects of child abuse and show an intergenerational transmission of the effects of poverty. The large sample size provides certain robustness to the findings even when some factor loadings were lower than 10 , but the relatively low magnitude of some coefficients suggest that additional research is needed to have confidence in these findings. These results also show the importance of conducting research on the gendered consequences of violence in the family of origin and contrasting the results between developing and developed countries, as well as research that addresses the role of the meso- and macro-social forces in sustaining the multiple causes of domestic abuse and violence reproduction. 


\section{References}

Appel, A. E., \& Holden, G. W. (1998). The co-occurrence of spouse and physical child abuse: A review and appraisal. Journal of Family Psychology, 12(4), 578-599. DOI: 10.1037/0893-3200.12.4.578

Arbuckle, J. (2006). User's Guide 1995-2006. Spring House: Amos Development Corporation.

Ateah, C. A., \& Durrant, J. E. (2005). Maternal use of physical punishment in response to child misbehavior: implications for child abuse prevention. Child Abuse Neglect, 29(2), 169-185. DOI: 10.1016/j.chiabu.2004.10.010

Azar, S. T. (1997). A cognitive-behavioral approach to understanding and treating parents who physically abuse their children. In D. A. Wolfe, R. J. McMahon \& R. D. Peters (Eds.), Child Abuse: New directions in prevention and treatment across the lifespan (pp.79-101). CA: Thousand Oaks.

Bandura, A. (1977). Social Learning. California: Prentice-Hall.

Barak, G. (2003). Violence and non-violence: pathways to understanding. Michigan, USA: Sage Publications Inc.

Barak, G. (2006). Applying integrative theory: A reciprocal theory of violence and nonviolence In S. Henry \& M. Lanier (Eds.), The essential criminology reader (pp.336346). Boulder, CO: Westview Press.

Baron, J. (Ed.) (2010). Documentos de trabajo sobre economia regional: La violencia de pareja en Colombia y sus regiones. Cartagena, Colombia: Banco de la Republica.

Bensley, L., Ruggles, D., Simmons, K. W., Harris, C., Williams, K., Putvin, T., \& Allen, M. (2004). General population norms about child abuse and neglect and associations with childhood experiences. Child Abuse Neglect, 28(12), 1321-1337. DOI: 10.1016/j.chiabu.2004.07.004

Bernard, M., \& Bernard, J. L. (1983). Violent intimacy: the family as a model for love relationships. Journal of Applied Family and Child Studies, 32(2), 283-286. DOI: $10.2307 / 584688$

Berrien, F. B., Aprelkov, G., Ivanova, T., Zhmurov, V., \& Buxhicheeva, V. (1995). Child abuse prevalence in Russian urban population: A preliminary report. Child Abuse \& Neglect, 19(2), 261-264. DOI: 10.1016/0145-2134(94)00124-D

Bonilla-Mejia, L. (Ed.) (2011). Dimension regional de las desigualdades en Colombia. Bogota, Colombia: Banco de la Republica, Biblioteca Luis Angel Arango.

Breiding, M. J., Basile, K. C., Smith, S. G., Black, M. C., \& Mahendra, R. (2015). Intimate partner violence surveillance uniform definitions and recommended data elements. Atlanta, Georgia: National Center for Injury Prevention and Control.

Briere, J., \& Elliott, D. M. (2003). Prevalence and psychological sequelae of self-reported childhood physical and sexual abuse in a general population sample of men and

Revista Española de Investigación Criminológica

Artículo 8, Número 16 (2018)

www.criminologia.net

ISSN: 1696-9219 
women. Child Abuse \& Neglect, 27(10), 1205-1222. DOI: 10.1016/j.chiabu.2003.09.008

Burtain-Ricklefs, J. J., Kemper, K. J., Bell, M., \& Babonis, T. (1994). Punishments: What predicts adult approval. Child Abuse \& Neglect, 18(11), 945-955. DOI: 10.1016/S0145-2134(05)80005-5

Camargo, E. (2009). Doctoral Dissertation Family violence under a multicultural perspective in Colombia. University of Nebraska at Omaha, Omaha, Nebraska (3365815).

Cardenas V., G., \& Polo Otero, J. L. (2014). Ciclo intergeneracional de la violencia domestica contra la mujer: analysis para las regiones de Colombia. Revista de Economia del Caribe, 14, 1-34.

Caykoylu, A., Ibiloglu, A. O., Taner, Y., Potas, N., \& Taner, E. (2011). The correlation of childhood physical abuse history and later abuse in a group of Turkish population. Journal of Interpersonal Violence, 26(17), 3455-3475. DOI: $10.1177 / 0886260511403748$

Cohen, J. (1990). Things I have learned (so far). American Psychologist, 45(12), 1304-1312.

Covey, H. C., Menard, S., \& Franzese, R. J. (2013). Effects of adolescent physical abuse, exposure to neighborhood violence, and witnessing parental violence on adult socioeconomic status. Child Maltreat, 18(2), 85-97. DOI: $10.1177 / 1077559513477914$

Davies, L., Ford-Gilboe, M., Willson, A., Varcoe, C., Wuest, J., Campbell, J., \& ScottStorey, K. (2015). Patterns of cumulative abuse among female survivors of intimate partner violence: links to women's health and socioeconomic status. Violence Against Women, 21(1), 30-48. DOI: 10.1177/1077801214564076

Devoe, E. R., \& Smith, E. L. (2002). The impact of domestic violence on urban preschool children: Battered mothers' perspectives. Journal of Interpersonal Violence, 17(10), 1075-1101. DOI: $10.1177 / 088626002236661$

Dietz, T. L. (2000). Disciplining children: characteristics associated with the use of corporal punishment. Child Abuse \& Neglect, 24(12), 1529-1542. DOI: 10.1016/S01452134(00)00213-1

Dobbs, T. A., Smith, A. B., \& Taylor, N. J. (2006). "No, we don't get a say, children just suffer the consequences": Children talk about family discipline. The International. Journal of Children's Rights, 14(2), 137-156. DOI: 10.1163/157181806777922694

Edleson, J. L. (1999). Children's witnessing of adult domestic violence. Journal of Interpersonal Violence, 14(8), 839-870. DOI: 10.1177/088626099014008004

Friedemann-Sanchez, G., \& Lovaton, R. (2012). Intimate Partner Violence in Colombia: Who is at Risk? Social Forces, 91(2), 663-688 . DOI: 10.1093/sf/sos131 
Gamez-Guadix, M., Straus, M., Carrobles, J. A., Munoz-Rivas, M., \& Almendros, C. (2010). Corporal punisment and long-term behavior problems: The moderating role of positive parenting and psychological aggression. Psicothema, 22(4), 529-536.

Gonzalez, M. R., Trujillo, A., \& Pereda, N. (2014). Corporal punishment in rural Colombia families: prevalence, family structure and socio-demographic variables. Child Abuse \& Neglect, 38(5), 909-916. DOI: 10.1016/j.chiabu.2013.10.006

Gratz, K. L., Paulson, A., Jakupcak, M., \& Tull, M. T. (2009). Exploring the Relationship Between Childhood Maltreatment and Intimate Partner Abuse: Gender Differences in the Mediating Role of Emotion Dysregulation. Violence and Victims, 24(1), 68-82. DOI: $10.1891 / 0886-6708.24 .1 .68$

Gutierrez de Pineda, V. (1962). La familia en Colombia: Estudio antropológico. Bogotá, Colombia: Universidad Nacional de Colombia.

Gutierrez de Pineda, V. (1963). La familia en Colombia: Transfondo histórico. Bogotá, Colombia: Universidad Nacional de Colombia.

Gutierrez de Pineda, V. (1968a). Familia y cultura en Colombia: Topologías, funciones y dinámica de la familia. Manifestaciones múltiples a través del mosaico cultural y sus estructural sociales. Bogotá, Colombia: Tercer Mundo Editores.

Gutierrez de Pineda, V. (1968b). Honor, familia y sociedad en la estructural patriarcal: El caso de Santander. Bogotá, Colombia: Universidad Nacional de Colombia.

Gutierrez de Pineda, V. (1975). Familia y cultura en Colombia: Tipologias, funciones y dinámica de la familia: Manifestaciones múltiples a través del mosaico cultural y sus estructuras sociales. Bogota, Colombia: Instituto Colombiano de Cultura, Subdireccion de Comunicaciones Culturales.

Hagan, J. (1988). Structural criminology. Cambridge: Polity.

Hagan, J., Simpson, J., \& Gillis, A. (1987). Class in the household: A power-control theory of gender and delinquency. American Journal of Sociology, 92(4), 788-816. DOI: $10.1086 / 228583$

Herrenkohl, T. I., Sousa, C., Tajima, E. A., Herrenkohl, R. C., \& Moylan, C. A. (2008). Intersection of child abuse and children's exposure to domestic violence. Trauma Violence Abuse, 9(2), 84-99. DOI: 10.1177/1524838008314797

Herrera, V., \& McCloskey, L. A. (2001). Gender differences in the risk for delinquency among youth exposed to family violence. Child Abuse \& Neglect, 25(8), 1037-1051. DOI: $10.1016 / \mathrm{S} 0145-2134(01) 00255-1$

Hetzel-Riggin, M. D., \& Meads, C. L. (2011). Childhood Violence and Adult Partner Maltreatment: The Roles of Coping Style and Psychological Distress. Journal of Family Violence, 26(8), 585-593. DOI: 10.1007/s10896-011-9395-z

Kandel, E. (1991). Physical punishment and the development of aggressive and violent behavior: A review. University of New Hampshire, Durham. New Hampshire.

Revista Española de Investigación Criminológica

Artículo 8, Número 16 (2018)

www.criminologia.net

ISSN: 1696-9219 
Klevens, J., Bayon, M., \& Sierra, M. (2000). Risk factors and context of men who physically abuse in Bogota, Colombia. Child Abuse \& Neglect, 24(3), 323-332. DOI: 10.1016/S0145-2134(99)00148-9

Leary, M. R. (2003). Introduction to Behavioral Research Methods (4th ed.). Boston: Allyn \& Bacon, Inc.

Lopez de Godoy, X. (2005). Creencias y patrones de crianza como factores incidentes de conductas maltratantes en las familias de cinco padres reclusos del establecimiento penitenciario y carcelario de Leticia. Especializacion en Prevencion del Maltrato Infantil. Bogota, Colombia: Pontificia Universidad Javeriana.

Mihalic, S. W., \& Elliott, D. (1997). A social learning theory model of marital violence. Journal of Family Violence, 12(1), 21-47. DOI: 10.1023/A:1021941816102

Muller, R. T., Hunter, J. E., \& Stollak, G. (1995). The intergenerational transmission of corporal punishment: A comparison of social learning and temperament models. Child Abuse \& Neglect, 19(11), 1323-1335. DOI: 10.1016/0145-2134(95)00103-F

Muthen, B. (1983). Latent variable structural equation modeling with categorical data. Journal of Econometrics, 22(1-2), 43-65. DOI: 10.1016/0304-4076(83)90093-3

Muthen, B. (1984). A general structural equation model with dichotomous, ordered categorical, and continous latent variable indicators. Psychometrika, 49(1), 115-132.

Muthen, L., \& Muthen, B. (2009). Mplus User's Guide. California: Muthen \& Muthen.

Observatorio de Politicas de las Familias. (2016). Tipologias de familias en Colombia: Evolucion 1993-2014 (Documento de Trabajo No. 2016-1). Bogota, Colombia.

Observatorio de Politicas de las Familias. (2016). Diferencias geograficos y sociales en las tipologias de familias en Colombia: 2014 (Documento de Trabajo No. 2016-1). Bogota, Colombia.

Oliver, J. E. (1993). Intergenerational transmission of child abuse: Rates, research, and clinical implications. The American Journal of Psychiatry, 150(9), 1315-1324. DOI: 10.1176/ajp.150.9.1315

Paez-Martinez, R. (2017). Tendencias de investigaciones sobre la familia en Colombia. Revista Latinoamericana de Ciencias Sociales, 15(2), 823-837. DOI: 10.11600/1692715x.1520331052016

Ragin, D. F., Pilotti, M., Madry, L., Sage, R. E., Bingham, L. E., \& Primm, B. J. (2002). Intergenerational Substance Abuse and Domestic Violence as Familial Risk Factors for Lifetime Attempted Suicide Among Battered Women. Journal of Interpersonal Violence, 17(10), 1027-1045. DOI: 10.1177/088626002236658

Salas, M. (2005). Transmision intergeneracional de la violencia intrafamiliar: evidencia para las familias colombianas. Desarrollo y Sociedad, (56), 285-337.

Sanapo, M. S., \& Nakamura, Y. (2011). Gender and physical punishment: the filipino children's experience. Child Abuse Review, 20(1), 39-56. DOI: 10.1002/car.1148

Revista Española de Investigación Criminológica

Artículo 8, Número 16 (2018)

www.criminologia.net

ISSN: 1696-9219 
Sidebotham, P., Golding, J., \& Study, T. A. (2001). Child maltreatment in the "Children of the Nineties" A longitudinal study of parental risk factors. Child Abuse \& Neglect, 25(9), 1177-1200. DOI: 10.1016/S0145-2134(01)00261-7

Simons, R. L., Johnson, C., Beaman, J., \& Conger, R. D. (1993). Explaining women's double jeopardy: Factors that mediate the association between harsh treatment as a child and violence by a husband. Journal of Marriage and the Family, 55(3), 713-723. DOI: $10.2307 / 353351$

Stith, S. M., Rosen, K. H., Middleton, K. A., Bush, A. L., Lundeberg, K., \& Carlton, R. P. (2000). The intergenerational transmission of spouse abuse: A meta-analysis. Journal of Marriage and the Family, 62(3), 640-654. DOI: 10.1111/j.17413737.2000.00640.x

Straus, M. (1991). Discipline and Deviance: Physical punishment of children and violence and other crime in adulthood. Social Problems, 38(2), 133-154. DOI: 10.1525/sp.1991.38.2.03a00010

Straus, M. (1994). Beating the Devil Out of Them: Corporal Punishment in American Families. San Francisco, CA: Jossey-Bass/Lexington.

Straus, M. (1994). Should the use of corporal punishment by parents be considered child abuse? Debating children's lives: Current controversies on children and adolescents. California: Sage Publications.

Straus, M. (1996). Social Change and the Trends in Approval of Corporal Punishment by Parents from 1968 to 1994. In D. Frehsee, W. Horn, \& K.-D. Bussmann (Eds.), Family violence against children: A challenge for society (pp.91-105). NY: Walter de Gruyter.

Straus, M. A., \& Mathur, A. K. (1996). Social Change and the Trends in Approval of Corporal Punishment by Parents from 1968 to 1994. In D. Frehsee, W. Horn, \& K.D. Bussmann (Eds.), Family Violence Against Children: A challenge for society (pp.91-105). NY: Walter de Gruyter.

Urrego, M. A. (1997). Sexualidad, matrimonio, y familia en Bogotá 1880-1930. Bogotá, Colombia: Universidad Central.

Viveros Vigoya, M. (2002). De quebradores y cumplidores: sobre hombres, masculinidades y relaciones de género en Colombia. Bogota, Colombia: CES, Univesidad Nacional de Colombia, Fundacion Ford, Profamilia.

Viveros Vigoya, M. (2003). Perspectivas Latinoamericanas Actuales Sobre Masculinidad. In P. T. Rojas (Ed.), Familia, Género y Antropología: Desafíos y Transformaciones (pp.82-130). Bogotá, Colombia: Instituto Colombiano de Antropología e Historia.

Wang, M., Xing, X., \& Zhao, J. (2014). Intergenerational transmission of corporal punishment in China: the moderating role of marital satisfaction and gender. Journal Abnorm Child Psychol, 42(8), 1263-1274. DOI: 10.1007/s10802-014-9890-9

Revista Española de Investigación Criminológica

Artículo 8, Número 16 (2018)

https://doi.org/10.46381/reic.v16i0.161

Www.criminologia.net

ISSN: 1696-9219 
Widom, C. S., Czaja, S., \& Dutton, M. A. (2014). Child abuse and neglect and intimate partner violence victimization and perpetration: a prospective investigation. Child Abuse Neglect, 38(4), 650-663. DOI: 10.1016/j.chiabu.2013.11.004

\section{Conflict of Interest Statement}

The corresponding author states that there is no conflict of interest.

\section{Acknowledgments}

I am very grateful to the MEASURE DHS for making the dataset available for analysis. I thank Dr. John Crank, Dr. Dona Castaneda, and Dr. Stuart Henry for their invaluable feedback at different stages of this article.

Esperanza Camargo received her doctorate from University of Nebraska, Omaha. She is currently an assistant professor of criminal justice at the School of Public Affairs, San Diego State University. She is currently interested on making international comparisons to measure the prevalence of family violence among various cultures, analyze the factors that influence family violence within these cultures, and compare the manifestations of family and domestic violence among these cultures.

iD https://orcid.org/0000-0001-8119-6583 